\title{
Comparative Analysis of Methodologies for the Evaluation of Geosites in the Context of the Santa Elena-Ancón Geopark Project
}

\author{
Gricelda A. Herrera-Franco $^{1 *}$, Paúl C. Carrión-Mero ${ }^{2,3}$, Carlos V. Mora-Frank ${ }^{1}$, Jhon K. Caicedo-Potosí ${ }^{4}$ \\ ${ }^{1}$ Universidad Estatal Península de Santa Elena, Facultad de Ciencias de la Ingeniería, La Libertad, Ecuador \\ ${ }^{2}$ ESPOL Polytechnic University, Escuela Superior Politécnica del Litoral, Centro de Investigación y Proyectos Aplicados a las \\ Ciencias de la Tierra (CIPAT), Guayaquil, Ecuador \\ ${ }^{3}$ ESPOL Polytechnic University, Escuela Superior Politécnica del Litoral, Facultad de Ingeniería en Ciencias de la Tierra \\ (FICT), Guayaquil, Ecuador \\ ${ }^{4}$ Junta Administradora de Agua Potable Regional Manglaralto, JAAPMAN, Manglaralto, Ecuador
}

Corresponding Author Email: grisherrera@upse.edu.ec

https://doi.org/10.18280/ijdne.150207

Received: 19 August 2019

Accepted: 20 November 2019

\section{Keywords:}

geodiversity, geosite evaluation, Santa Elena geopark project

\begin{abstract}
The Santa Elena province in Ecuador has great geodiversity potential, due to its geological characteristics and its coastal and marine context, as verified by publications about geosites, which have allowed the approach and development of initiatives in a context of geodiversity and sustainability. The aim of this article is to analyze 10 geosites from the Santa Elena province comparatively using the Brilha methodology, Geological and Mining Institute of Spain (IGME) methodology, and geosites assessment methodology (GAM) for the establishment of methodological considerations in the evaluation of geosites. These methodologies consider (i) 10 of the most representative geosites of the province for a comparative analysis; (ii) the application of the methodologies Brilha, IGME, and GAM to 10 geosites to establish the corresponding assessments; (iii) a comparative matrix of the results and analysis of the resulting assessment; and (iv) a proposal for the guidelines of an integrating methodology concerning geosites. The results show a similar ranking of 10 geosites, but highlight valuations that prioritize one aspect over another or focus on ecotourism aspects or geoconservation aspects. Based on the results and the comparative matrix, a method is structured integrating geodiversity, protection, geo-conservation, and geotourism aspects, which offer a different ranking of the considered geosites, being the most valued geosites the Chocolatera, Olón Cliff, Ancon Oilfield, and Manglaralto Coastal Aquifer.
\end{abstract}

\section{INTRODUCTION}

The geosites that exist in each country are a characteristic and essential review of what the historical, geological, biological, and tourist potential they represent and that a way for local development is encouraged through geoparks initiatives [1]. These are places of natural occurrence with high scientific, educational, and aesthetic value. Areas having elements such as minerals, fossils, rocks, and geoforms belong to geodiversity and through methodological studies, such as scientific publications, lead a geosite to be recognized as a national geological heritage. The valuation of each geosite in a given region favors the geoeducation of the inhabitants and visitors. This education process encourages geoconservation and, in turn, the scientific knowledge of each geosite [2-4]. These geosites represent to the local communities an added value that can improve their economy, taking advantage of their geo-diversity, biodiversity, and their culture [5]. A geosite has diverse definitions. For example, Serrano et al. [6] report that a geosite is the variety of abiotic nature, including lithological, tectonic, geomorphological, edaphic, hydrological, topographic, and physical processes on the earth's surface, the seas, and oceans, together with systems generated by natural, endogenous, exogenous, and anthropic processes, comprising the diversity of particles, elements, and places.

Geodiversity and biodiversity are fundamental components of natural resources of each country [7]; with the anthropogenic increase that negatively influences these components, their wealth and diversity are increasingly vulnerable and there is a need to preserve both geodiversity and biodiversity for future generations [8]. Nowadays, geodiversity encompasses a wide range of information about earth, which includes terrestrial and aquatic components. Potential geosites embrace representativeness, rarity, uniqueness, integrity, and scientific knowledge [9]. Rural communities are considered guardians of historical heritage and their culture; in these communities, geological heritage promotes social inclusion and intercultural dialogue [10].

'Geopark Context' is understood from the proposal created at the end of the last century, as a strategy for the protection of geological heritage through geopark projects [11]. Buenrostro [12] states that a geopark is an integrated concept of protection, education, and sustainable development. A geopark meets its objectives through conservation, education, and geotourism approach; hence, geosites are an essential point for the creation of a geopark. Taking into account that concepts will help in the development of the Santa Elena Geopark project [13], this 
article aims to analyze comparatively 10 geosites in the province of Santa Elena using the Brilha methodology, Spanish Inventory of Geological Sites of Interest (IELIG) methodology, and Geosites Assessment Methodology (GAM). These methodologies are common for the establishment of considerations in the evaluation of geosites, which are connected with reality.

For the development of the valuation of geosites, it is necessary to take into account certain existing variables in the methodologies that are needed and, in turn, aggregate variables that do not exist in the current methodologies (IELIG, Brilha, GAM). Later, will be based on the realization of an integrating matrix for the valuation of geosites through a result analysis to cover all the expectations that each geosite has. In fact, every geosite in the province must be assessed. However, in the present research, 10 geosites will be evaluated as a pilot project.

It is known that each of the methodologies to be used (IELIG, Brilha, GAM) are methodological processes containing different definitions, similar variables, and the same purpose (the valuation of geosites). For example, Brilha is based solely on the inventory and the most valuable quantitative evaluation of geodiversity events, hence, the priorities in site management $[14,15]$. The IELIG is based on the consultation of experts in each geological domain to cover different values, thus, proposing a universal method in different geosites. GAM is based on a preliminary model of physical evaluation of the geosite that has the potential to help in sustainable planning and management to transform them into tourist places.

Although the processes are different, they are potentialized in various fields because they serve as a primary method for the assessment of each of the geosites to evaluate. Thus, Brilha methodology deals with the great importance of geoconservation [16]. The conservation of nature is a primary point for the evaluation of geosites. IELIG is a systematic methodology based on the study of each variable; with this methodology, it is a question of covering the geological themes that exist as a place of interest [17]. Therefore, studies are carried out contributing to a general evaluation of the geosite; this is the way the assessment will be carried out in each geosite located in the Province of Santa Elena. The GAM methodology considers scientific and educational values, mainly, in such a way that it mentions the scenic/ aesthetic potential, and an important point such as the level of protection and human participation in the geosites [18]. All of the above will be detailed with more precision in the development of this article.

There is another methodology for the valuation of geosites, the Analytical Hierarchy Method (AHP), developed by Dr. Thomas L. Saaty during the 1970s [19], whose purpose is to employ qualitative and quantitative variables against multiple objectives through deter- mined values, which seek to give guidance in decision-making. Bolaños et al. [20] report that by valuing the geological sites of interest, one can understand the geological processes that have evolved on earth, in addition to encouraging the interest of society with the phenomena that occur in its environment.

\section{CASE STUDY}

The province of Santa Elena has stood out in being visited by many tourists every year; so, in the summertime, certain tourist spots are saturated by national and foreign visitors [21]. The location has a great variety of beaches along with its territorial and coastal maritime extension. In terms of its biodiversity, the province is characterized by its terrestrial and marine environments and its highly recognized geodiversity. By taking advantage of the above-mentioned characteristics, the Ancón-Santa Elena Geopark project is born to boost geotourism. There are some geosites which are more visited or recognized by tourists compared with others. Therefore, it is necessary to consider that issue, when assessing all points of interest in the Ancón-Santa Elena Geopark project. In terms of this study, a methodology capable of potentiating those places to consider will be taken into account as a general and essential point, be it, geological, biological, or geotouristic, regardless of its potential according to studies carried out in different geosites such as La Chocolatera, the Olón Cliff [22], Manglaralto Aquifer [23], Megatherium Paleontological Museum, Ancón Oil Camp, San Vicente Hot Springs, Two Man Trail, Bituminous Exudations, Cerro Capay Viewpoint, and El Pelado Marine Reserve.

\section{METHODOLOGY}

\subsection{General information}

Figure 1 represents the general methodology used in this study. This flow chart has three phases. The first phase comprises the literature review and the selection of the geosites sub- sequently assessed with each methodology (IELIG, Brilha, GAM). The second phase comprises the analysis of the methods for the valuation of geosites mentioned above and their application on the geosites of the Province of Santa Elena. Finally, the third phase consists of the comparative matrix of methodologies, prepared to finally propose the integrating matrix of geosite valuation.

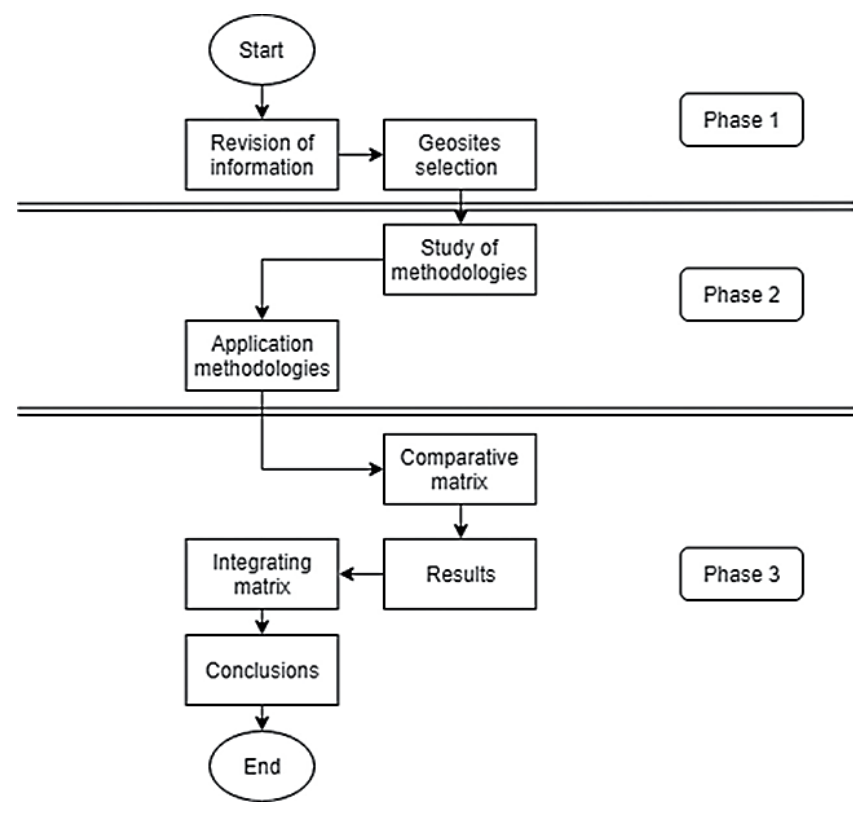

Figure 1. Methodological scheme

\subsection{Most representative geosites in the Province of Santa} Elena, Ecuador

Below (Table 1) are the most representative geosites in the 
Santa Elena Peninsula, according to studies already carried out and consulting experts. Codes were assigned to the 10 geosites and were classified as geosites of geological interest (GS) and geosites of industrial interest (IS) [13]; we selected the following geosites for their uniqueness, their geological characteristics, and their surrounding nature, and they are described in the following table.

Table 1. Geosites considered for the methodological assessment study

\begin{tabular}{ll}
\hline Geosites/code & Description \\
\hline & La Chocolatera is deemed as one of the most \\
& visited places every year by both national and \\
& international tourists; it is the most protruding \\
& point in the West Pacific in all Continental \\
1. & Ecuador (except for the Galapagos Islands). \\
GS8 & The Peninsula has quaternary tectonism with \\
& a Northwest-Southeast direction; such an \\
& elevation allowed the growth or outcrop of \\
& shale rocks (compact and with a high degree \\
& of solidification, giving them more \\
& resistance). \\
\hline Olón & It is approximately 70 m above sea level, \\
& consisting of sandstone rock, and it is \\
& interspersed with small layers of clay rocks. \\
& One of the most important religious temples \\
& in the Province is built there (built in 1984 by \\
& Father Othmar Staheli in collaboration with \\
the villagers). It allows us to have a & spectacular viewpoint, to contemplate the \\
& surrounding beaches, nature, and the Pacific \\
& Ocean.
\end{tabular}

Manglaralto is the parochial head located to the west of the province of Santa Elena and one of the most critically populated areas of the region. It has an underground aquifer 3. Manglaralto located at the foot of the Chongón-Colonche coastal aquifer/ mountain range, hence its water filtration, GS12 which extends to the parish of Manglaralto, filtering on the surface creating a place for its inhabitants and visitors; there are six deepwater wells for the supply of the commune and its surroundings.

The Santa Elena Peninsula State University (UPSE) has the only paleontological museum which contains findings from the Pliocene4. Megatherium Pleistocene era. Throughout its history, it has paleontological stood out as a tourist and representative place museum/IS8 of the province. It is located at the UPSE University of La Libertad-Santa Elena; it is considered in the Ancón-Santa Elena Geopark project.

As history indicates, the first oil well of Ecuador was drilled in 1911 in Ancon, in the Santa Elena Peninsula by Englishmen working for ANCÓN OIL COMPANY. This parish has a great history, geological, and 5. Ancón Oilfield biological riches, a culture that left a marked /IS2 product of times those in which the English lived and worked with Ecuadorians of the peninsula, hence, the old English Quarter, recognized as patrimony by the Ministry of Culture and Heritage from Ecuador.

This geosite contains thermal waters, which are physically medicinal for the body of the 6. San Vicente human being. San Vicente is geologically Hot Springs/ GS6 recognized for holding this intrinsic or unique value at the province level and which is recognized nationally and internationally,

\begin{tabular}{ll}
\hline & $\begin{array}{l}\text { Suarez [24] mentions, 'it is the second most } \\
\text { important mineralized pool in the world after } \\
\text { the first one located in Germany'. }\end{array}$ \\
\hline $\begin{array}{l}\text { 7. Dos Mangas characterized by containing an attractive } \\
\text { geological center with varieties of options for } \\
\text { geotourism such as the Dos Mangas } \\
\text { waterfall, the natural pools, its route through } \\
\text { nature, and the Dos Mangas culture that are } \\
\text { characterized by the inhabitants of that } \\
\text { commune. }\end{array}$ \\
\hline B. Bituminous \\
exudations/ IS6 & $\begin{array}{l}\text { There are various points around the Santa } \\
\text { Elena Province which emanate oil naturally } \\
\text { from the oil reservoirs. }\end{array}$ \\
\hline Viewpoint/ GS28 & $\begin{array}{l}\text { This is a geological attractive site. Being a } \\
\text { viewpoint, which allows people to witness, } \\
\text { thanks to its geological formation, part of the }\end{array}$ \\
& $\begin{array}{l}\text { North, to the West the Pacific Ocean can be } \\
\text { observed, and Southwest is La Puntilla of the } \\
\text { province of Santa Elena. }\end{array}$ \\
\hline 10. & $\begin{array}{l}\text { This is an islet which contains a great variety } \\
\text { of geological and biological attractions; it is } \\
\text { located to the Northwest of the Province of } \\
\text { Santa Elena. It has underwater caves, striking } \\
\text { for both Ecuadorian and foreign tourists, } \\
\text { Pelado"/ GS14 } \\
\text { large numbers of marine animals arrive } \\
\text { taking refuge in this place. Its geodiversity } \\
\text { and biodiversity give it an appropriate } \\
\text { potential to be selected as a geosite in the } \\
\text { Ancón-Santa Elena Geopark project }\end{array}$ \\
\hline
\end{tabular}

\subsection{Application of the Brilha methodology, IELIG methodology, and GAM to the 10 geosites to establish the corresponding valuations}

Table 2 contains the assigned values for the evaluation of each geosite considering the three methodologies used.

Table 3 mentions, in a general way, the variables that each of the methodologies considers, Brilha, IELIG, and GAM, in such a way that it serves as a guide for the matrix elaboration.

Table 2. Assessment for the methodologies: Brilha, IELIG, and GAM

\begin{tabular}{ccc}
\hline Rating grade & Variable value & Description \\
\hline Very low & 1 & $\begin{array}{c}\text { Does not meet the variable } \\
\text { Contribute slightly to the } \\
\text { variable }\end{array}$ \\
Middle & 2 & $\begin{array}{c}\text { It regularly complies with } \\
\text { this variable } \\
\text { It has a high index in the } \\
\text { valued variable } \\
\text { High }\end{array}$ \\
Very high & 5 & $\begin{array}{c}\text { Fully complies with the } \\
\text { variable }\end{array}$ \\
\hline
\end{tabular}

Both Brilha methodology and the GAM value only geosites, while the IELIG methodology values geosites and mining sites. The Brilha methodology considers mainly education variables and the value related to tourism and the rarity of the geosite, whereas the IELIG methodology considers the rarity of the geosite and the scientific one within the intrinsic value; the GAM methodology has different variables to assess the scientific level of the geo site and its aesthetics.

For comparison, we obtained a total by multiplying the total amount of variables, depending on each methodology, by the maximum value (five), set in Table 2 ; in the same way, it is weighted for 100 to develop a better emphasis on the comparative matrix, established in Table 4. 
Table 3. Comparative table of methodologies

\begin{tabular}{|c|c|c|c|c|c|}
\hline Method & & & Variables & & \\
\hline Brilha & Educational value & Touristic value & & & \\
\hline IELIG & Intrinsic value & Touristic value & Use and protection values & Didactic value & \\
\hline GAM & Educational and scientific values & Touristic value & Protection value & Functional value & Scenic value \\
\hline
\end{tabular}

Table 4. Comparative results matrix

\begin{tabular}{cccc}
\hline \multirow{2}{*}{ Geosites } & \multicolumn{3}{c}{ Methodologies } \\
\cline { 2 - 4 } & Brilha & IELIG & GAM \\
\hline GS8 & 92 & 92 & 79 \\
GS15 & 79 & 76 & 67 \\
GS12 & 74 & 72 & 63 \\
IS8 & 88 & 93 & 91 \\
IS2 & 80 & 77 & 74 \\
GS6 & 74 & 75 & 74 \\
GS25 & 85 & 84 & 87 \\
IS6 & 63 & 67 & 59 \\
GS28 & 67 & 68 & 59 \\
GS14 & 76 & 79 & 76 \\
Average total & $77.8 / 100$ & $78.3 / 100$ & $72.7 / 100$ \\
\hline
\end{tabular}

Then, each of the methodologies is briefly drafted, in such a way that the definitions and variables of each one are mentioned, for the study of valuation of a place of interest, and in the same way, the valuation corresponding to each one of the geosites is selected depending on the methodology to be used for the evaluation.

\subsubsection{Brilha's methodology}

This methodology is strategically based on geoconservation through the review of geodiversity for the valuation of geosites. Therefore, several processes must be carried out for a selection such as inventory, quantitative assessment, conservation, interpretation and promotion, and, finally, site monitoring. Brilha aims to study inventory (scientific value) and quantitative evaluation. This methodology uses secondary information, that is, data or research that has already been carried out in the place of interest and sources of primary information based on the author's experience; they serve as support to define the logical framework in the study of the geosites.

Brilha takes into account the importance of reviewing the literature to know the geological environment of the area and determine a list of possible geosites. Hence, it means to have the necessary characteristics to cover the requirements that a geosite must have (representative- ness, integrity, rarity, and scientific knowledge), otherwise, the geosites which do not comply with the mentioned characteristics, will face elimination from that list.

\subsubsection{IELIG methodology}

This methodology is characterized by being systematic and universal as it aims to cover all the geological, biological, and geotouristic disciplines. Therefore, depending on the geological value (main point), the geosites consider one or more of the interest indexes, such as stratigraphic, sedimentological, geomorphological, paleontological, or geological history.

\subsubsection{GAM methodology}

This process complies with different variables from the other methodologies, except scientific value, which has an essential part of each of these methods for their assessment. Therefore, the aim of the GAM is to look at scientific and educational values of notable sceneries from various viewpoints, landscapes and surrounding nature, level of protection, and human participation. Thus, if there is a limit of visits in a period of time, it must be respected as a protected or heritage site, with the aim of not altering its image.

\section{RESULTS}

\subsection{General information}

This comparative matrix (Table 5 and 6) looks at the results obtained in the previous matrices, according to the variables and sub-variables considered to be the quantitative representation of each of the methodologies (GAM, Brilha, IGME). Therefore, it serves as an important basis to determine the most convenient process in the study of geosites, and it provides the necessary emphasis to each of the methodologies in their acceptance and assessment.

Table 5. Proposal of an integrating matrix for the valuation of geosites, made by authors

\begin{tabular}{|c|c|c|c|c|c|}
\hline \multicolumn{6}{|c|}{ Integrating matrix } \\
\hline Variables & GS8 & GS15 & GS12 & IS8 & IS2 \\
\hline \multicolumn{6}{|c|}{ Scientific } \\
\hline Geoscience values & 5 & 4 & 4 & 5 & 5 \\
\hline Key location & 4 & 4 & 3 & 4 & 4 \\
\hline Geodiversity & 5 & 5 & 4 & 3 & 4 \\
\hline Limitations of use & 5 & 4 & 5 & 4 & 4 \\
\hline $\begin{array}{l}\text { Degree of scientific } \\
\text { knowledge }\end{array}$ & 5 & 4 & 5 & 5 & 5 \\
\hline \multicolumn{6}{|c|}{ Scenic/aesthetic } \\
\hline Spectacular & 5 & 5 & 4 & 5 & 4 \\
\hline $\begin{array}{l}\text { Landscape and nature } \\
\text { surroundings }\end{array}$ & 4 & 5 & 4 & 3 & 4 \\
\hline Environmental adjustment & 5 & 4 & 3 & 4 & 3 \\
\hline Geosite extension & 5 & 3 & 5 & 3 & 5 \\
\hline \multicolumn{6}{|c|}{ Protection } \\
\hline Current condition & 5 & 4 & 3 & 5 & 3 \\
\hline Protection level & 5 & 4 & 4 & 5 & 4 \\
\hline Vulnerability & 4 & 3 & 3 & 5 & 3 \\
\hline Geoconservation & 4 & 4 & 5 & 3 & 3 \\
\hline \multicolumn{6}{|c|}{ Functional value } \\
\hline Accessibility & 5 & 4 & 4 & 5 & 4 \\
\hline Anthropogenic value & 3 & 2 & 3 & 5 & 3 \\
\hline Natural values & 5 & 3 & 4 & 4 & 3 \\
\hline \multicolumn{6}{|c|}{$\begin{array}{l}\text { Geotouristic value } \\
\end{array}$} \\
\hline Interpretation panels & 4 & 3 & 2 & 5 & 3 \\
\hline Touristic infrastructure & 4 & 3 & 3 & 5 & 4 \\
\hline Logistics & 5 & 4 & 4 & 5 & 4 \\
\hline Disclosure potential & 5 & 4 & 4 & 5 & 5 \\
\hline Fragility & 5 & 4 & 3 & 5 & 4 \\
\hline Guide service & 4 & 3 & 3 & 5 & 4 \\
\hline Media adaptation services & 5 & 5 & 3 & 5 & 4 \\
\hline Total over 115 & 106 & 88 & 85 & 103 & 89 \\
\hline Total equivalent to 100 & 92 & 77 & 74 & 90 & 77 \\
\hline
\end{tabular}


Table 6. Proposal of an integrating matrix for the valuation of geosites, made by authors

\begin{tabular}{|c|c|c|c|c|c|}
\hline \multicolumn{6}{|c|}{ Integrating matrix } \\
\hline Variables & GS6 & GS25 & IS6 & GS28 & GS14 \\
\hline \multicolumn{6}{|c|}{ Scientific } \\
\hline Geoscience values & 5 & 4 & 4 & 3 & 4 \\
\hline Key location & 4 & 4 & 3 & 3 & 4 \\
\hline Geodiversity & 3 & 5 & 4 & 4 & 5 \\
\hline Limitations of use & 4 & 5 & 3 & 3 & 4 \\
\hline $\begin{array}{c}\text { Degree of scientific } \\
\text { knowledge }\end{array}$ & 5 & 4 & 4 & 4 & 4 \\
\hline \multicolumn{6}{|c|}{ Scenic/aesthetic } \\
\hline Spectacular & 5 & 4 & 4 & 4 & 5 \\
\hline $\begin{array}{c}\text { Landscape and nature } \\
\text { surroundings }\end{array}$ & 3 & 5 & 3 & 4 & 5 \\
\hline $\begin{array}{c}\text { Environmental } \\
\text { adjustment }\end{array}$ & 3 & 5 & 3 & 3 & 4 \\
\hline Geosite extension & 4 & 5 & 5 & 5 & 4 \\
\hline \multicolumn{6}{|c|}{ Protection } \\
\hline Current condition & 3 & 4 & 4 & 3 & 3 \\
\hline Protection level & 4 & 4 & 4 & 3 & 5 \\
\hline Vulnerability & 4 & 4 & 4 & 4 & 4 \\
\hline Geoconservation & 3 & 5 & 4 & 4 & 5 \\
\hline \multicolumn{6}{|c|}{ Functional value } \\
\hline Accessibility & 4 & 5 & 3 & 4 & 4 \\
\hline Anthropogenic value & 3 & 5 & 3 & 3 & 4 \\
\hline Natural values & 3 & 5 & 5 & 4 & 5 \\
\hline \multicolumn{6}{|c|}{ Geotouristic value } \\
\hline Interpretation panels & 3 & 4 & 2 & 2 & 4 \\
\hline Touristic infrastructure & 3 & 5 & 1 & 2 & 3 \\
\hline Logistics & 4 & 4 & 3 & 4 & 4 \\
\hline Disclosure potential & 4 & 5 & 3 & 4 & 5 \\
\hline Fragility & 3 & 5 & 3 & 4 & 5 \\
\hline Guide service & 3 & 5 & 4 & 4 & 5 \\
\hline $\begin{array}{c}\text { Media adaptation } \\
\text { services }\end{array}$ & 3 & 4 & 3 & 3 & 5 \\
\hline Total over 115 & 83 & 105 & 79 & 81 & 97 \\
\hline Total equivalent to 100 & 72 & 91 & 69 & 70 & 96 \\
\hline Average value & 80.8 & & & & \\
\hline
\end{tabular}

The comparative matrix of results reaches several essential issues for its understanding, in such a way that the average total is the sum of the result obtained in each geosite for a given methodology and varies according to the number of variables that consider these methodologies.

To make the matrix results clearer, it is necessary to say that the IELIG methodology obtained the highest score in connection with the other methodologies with a value of 78.3, followed by Brilha with 77.8 , and finally GAM with 72.7 points.

The IELIG methodology considers several parameters for the assessment study of the 10 selected geosites and it may be an effective aid to increase relevant research on the AncónSanta Elena Geopark project.

\subsection{Analysis of results}

In the integrating matrix, variables such as the degree of scientific knowledge, which refers to how much has been explored and the studies that have been carried out on the geosite, have been added. The extent of the geosite is the geographic size occupied by the geosite of a local region.

The most important variables are scientific, aesthetic, protection, and geotourism because we can evaluate the geosites and their main characteristics using them. The average value with the integrating matrix is higher than the average values obtained with the other methodologies because we consider additional valuation parameters such as geoconservation, which assesses whether the geosite indicates geoconservation for its permanence in time, and the variable adaptation services in the middle so that the geotourist can adapt to the geosite he visits.

\section{CONCLUSIONS}

The elaboration of a new methodology in the valuation of the geosites of the Ancón-Santa Elena Geopark project involves the creation of an integrating matrix, which includes the aspects of the IELIG methodology, GAM, and Brilha methodology. Moreover, the matrix, and adds variables that cover the geological, biological, and touristic characteristics that the geosites selected for the Geopark project have recognition of national and international heritage.

The Brilha methodology and the GAM apply only to geosites, and the IELIG methodology applies to geosites and mining sites. All of them consider five values: scientific, scenic/aesthetic, protection, functional, and geotouristic. In the new Integrative Matrix for the Evaluation of Geosites (MIEG), additional parameters were considered, with the purpose of covering the expectations that are boosted in the geosites of the Santa Elena geopark project.

According to the ratings obtained by the geosites with the methodology of the MIEG, a higher average value is collected in relation to the average scores of the Brilha methodology, IGME methodology, and GAM. In the process of the present research, it fulfills the objective of the valuation of the geosites in the Santa Elena project.

\section{ACKNOWLEDGMENT}

To the UPSE University Research Project "Proyecto Geoparque Peninsula de Santa Elena”

To the ESPOL Polytechnic University Research Project "Registro de patrimonio geológico y minero y su incidencia en la defensa y preservación de la geodiversidad en el Ecuador."

\section{REFERENCES}

[1] Herrera, G., Álvarez, A., Alvarado, N. (2016). La Minería y la Geología ambiental herramientas para el desarrollo sostenible, para el presente futuro. Libro de actas del Cuarto Congreso Internacional sobre Geología Y Minería Ambiental para el ordenamiento del territorio y el desarrollo, 1(1): 355-369.

[2] Prosser, C., Díaz, E., Larwood, J. (2018). The conservation of geosites: Principles and practice. In: Reynard, E. \& Brilha, J. (eds) Geoheritage Assessment, Protection, and Management. Elsevier, Amsterdam. http://dx.doi.org/10.1016/B978-0-12-809531-7.00011-3

[3] Mendia, M., Hilario, A., Aranburu, A., Carracedo, M., Cearreta, A., Eguíluz, L., Gil-Crespo, P., González, M., Martínez-Torres, L., López-Horgue, M., Murgerza, I. (2012). El inventario de lugares de interés geológico de la comunidad autónoma del País Vasco (CAPV). In: Vegas, J., Salazar, A., Díaz-Martínez, E. \& Marchán, C. (eds) Patrimonio geológico, un recurso para el desarrollo. Instituto Geológico y Minero de España, Madrid. ISBN 978-84-7840-901-3 
[4] Ojeda, G., Lacreu, H., Sosa, G., Gómez, H., Dueñas, D. (2008). Atlas de recursos geoambientales: Municipio de Juana Koslay. Universidad de San Luis, Argentina.

[5] Lazzari, M., Aloia, A. (2014). Geoparks, geoheritage and geotourism: Opportunities and tools in sustainable development of the territory. Geojournal of Tourism and Geosites, 13(1): 8-9.

[6] Serrano, E., Ruiz, P., Arroyo, P. (2009). Geodiversity assessment in a rural landscape: Tiermes Caracena area (Soria, Spain). Memorie Descrittive Della Carta Geologica d'Italia, 86(1): 171-178.

[7] Medina, W. (2015). Importancia de la Geodiversidad. Métdodo para el inventario y valoración del Patrimonio Geológico. Serie Correlación Geológica, 31(1): 57-72.

[8] Erikstad, L. (2013). Geoheritage and geodiversity management-The questions for tomorrow. Proceedings of the Geologists' Association, 124(4): 713-719. https://doi. org/10.1016/j.pgeola.2012.07.003

[9] Çetiner, Z.S., Ertekin, C., Yiğitbaş, E. (2017). Evaluating scientific value of geodiversity for natural protected sites: The Biga Peninsula, Northwestern Turkey. Geoheritage, 10(1): 49-65. https://doi.org/10.1007/s12371-017-02183

[10] Carrión, P., Herrera, G., Briones, J., Sánchez, C. (2018). La Geodiversidad, una componente de desarrollo sostenible. Journal of Science and Research: Revista Ciencia e Investigación, 3(1):. 36-42. https://doi.org/10.26910/issn.25288083vol3issICCE2018.2018pp45-52p

[11] Palacio, J. (2013). Geositios, geomorfositios y geoparques: Importancia, situación actual y perspectivas en México. Investigaciones Geográficas, Boletín del Instituto de Geografía, 82(1): 24-37. https://doi.org/10.14350/rig.32817

[12] Buenrostro, D. (2015). Propuesta de geositios a lo largo del borde litoral y sendero Ensenada Grande 3 en la isla La Partida y del sendero Cascada Seca en la isla Espíritu Santo, Baja California Sur, México. Engineer dissertation. Departamento Académico de Geología Marina, Universidad Autónoma de Baja California Sur, Baja California Sur, México.

[13] Herrera, G., Carrión, P., Josué, B. (2018). Geotourism potential in the context of the Geopark project for the development of Santa Elena Province, Ecuador. WIT Transactions on Ecology and the Environment, 217(1): 557-568. http://dx.doi.org/10.2495/SDP180481

[14] Brilha, J. (2014). Inventory and quantitative assessment of geosites and geodiversity sites: A review. Geoheritage, 8(2): 119-134. https://doi.org/10.1007/s12371-0140139-3

[15] De Lima, F., Brilha, J., Salamuni, E. (2010). Inventorying geological heritage in large. Territories: A methodological proposal applied to Brazil. Geoheritage, 2(3-4): 91-99. https://doi.org/10.1007/s12371-010-00149

[16] Sánchez, J., Brilha, J. (2015). Datos Preliminares para una Estrategia de Geoconservación de las Estructuras de Impacto del Brazil. In: Hilario, A., Mendia, M., Monge, M., Fernández, E., Vegas, J. \& Belmonte, A. (eds)
Patrimonio geológico y geoparques, avances de un camino. Instituto Geológico y Minero de España, Madrid. ISBN 978-84-7840-962-4.

[17] García, A., Carcavilla, L. (2013). Documento metodológico para la elaboración del Inventario Español de Lugares de Interés Geológico (IELIG). In: García, A. \& Carcavilla, L. (eds) Instituto Geológico y Minero de España, Madrid.

[18] Vujičić, M., Vasiljević, D., Marković, S., Hose, T., Lukić, T., Hadzić, O., Janicević, S. (2011). Preliminary geosite assessment model (GAM) and its application on fruska gora mountain, potential geotourism destination of Serbia. Acta Geographica Slovenica, 51(2): 361-377. https://doi.org/10.3986/AGS51303

[19] Sánchez, G. (2003). Técnicas Participativas para la Planeación. In: Sánchez, G. (ed) Fundación ICA, México.

[20] Bolaños, M., García, A., Villavicencio, A., Viteri, F. (2016). Metodología para la determinación de lugares de interés geológico: Caso "Trayecto: Baeza-San Víctor-El Chaco". Figempa investigación y desarrollo, 1(1): 53-58. https://doi.org/10.29166/revfig.v1i1.46

[21] Rodriguez, A., Rodriguez, E. (2014). Plan de desarrollo turístico para las comunidades de Pajiza, Río Chico, Cadeate y San Antonio pertenecientes a la parroquia Manglaralto, cantón Santa Elena, provincia de Santa Elena, año 2014. Engineer dissertation. Facultad de Ciencias Administrativas, Universidad Estatal Península de Santa Elena, La Libertad, Ecuador.

[22] Sánchez, J. (2010). Manejo sustentable de puntos de interés geoturísticos (PIGT), sobre la base de la caracterización y evaluación, en la Península de Santa Elena. Master dissertation. Facultad de Ciencias Naturales, Universidad Estatal de Guayaquil, Guayaquil, Ecuador.

[23] Herrera, G. (2015). Estudio para un Modelo de Gestión de un Acuífero Costero, mediante Metodologías Participativas y Análisis Geoestadístico en el marco del Desarrollo Local. Manglaralto, Ecuador. Ph.D. dissertation. Departamento de Ingeniería Topográfica y Cartografía, Universidad Universidad Politécnica de Madrid, Madrid, España.

[24] Suárez, A. (2012). Impacto de la administración comunitaria del complejo termal "telésforo villacrés" para el desarrollo del turismo sostenible en los baños de San Vicente. Engineer dissertation. Facultad de Ciencias Administrativas, Universidad Estatal Península de Santa Elena, La Libertad, Ecuador.

\section{NOMENCLATURE}

$\begin{array}{ll}\text { IGME } & \begin{array}{l}\text { Geological and Mining Institute of Spain } \\ \text { geosites assessment methodology }\end{array} \\ \text { IELIG } & \begin{array}{l}\text { Spanish Inventory of Geological Sites of } \\ \text { Interest }\end{array} \\ \text { AHP } & \text { Analytical Hierarchy Method } \\ \text { GS } & \text { geosites of geological interest } \\ \text { IS } & \text { geosites of industrial interest }\end{array}$

